УДК 611.146.6.013

O.M. Slobodian, V.S. Sambirskii, D.V. Proniaiev

Department of Anatomy, Topographic Anatomy and Operative Surgery (Head-Prof. O.M. Slobodian) of

Bukovinian State Medical University, City of Chernivtsi

\title{
PERINATAL ANATOMY OF THE PAMPINIFORM PLEXUS AND TESTICULAR VEINS
}

\section{ПЕРИНАТАЛЬНА АНАТОМІЯ ЛОЗОПОДІБНОГО СПЛЕТЕННЯ ТА ЯЄЧКОВИХ ВЕН}

Резюме. Тлумачення результатів дослідження і обсяг оперативних втручань 3 приводу варикоцеле пов'язане з детальним і грунтовним вивченням анатомії вен сім'яного канатика. Водночас аналіз наукових джерел засвідчує, що відомості про анатомію венозних лозоподібних сплетень та яєчкових вен уривчасті, одиничні та несистематизовані. Дослідження проведено на 70 трупах плодів та 15 трупах новонароджених людини чоловічої статі. Встановлена асиметрія величини діаметра та форми просвіту вен сплетення сім'явиносної протоки, справа ці параметри мінливіші, ніж зліва. На рівні голівки правого над'яєчка помітні розширені круглясті просвіти судин венозних сплетень, а відстань між сім'явиносною протокою та іiі артерією значно більша, ніж зліва. За межами над’яєчка венозні сплетення прямують уздовж сім'явиносної протоки та іiі артерії, анастомозуючи між собою, що $є$ підставою стверджувати про існування спільного венозного сплетення навколо цих структур.

Ключові слова: лозоподібне сплетення, яєчкові вени, плід, анатомія, людина.

In spite of the progress of modern surgical technologies numerous methods of surgical treatment of varicocele are not always effective. Undoubtedly, such situation resulted from the fact that while performing this or that surgical maneuver physicians do not consider certain anatomical peculiarities of the testicular venous plexus and spermatic cord. Varicocele is an element of the collateral renocaval anastomosis which occurrence is indicative of the obstruction of the renal vein or disorders of flow into the iliac vein [1]. According to different data the frequency of this pathology achieves $20 \%$. Varicocele is a cause of male sterility in $50 \%$ of men. The frequency of relapse of this pathology after treatment by means of various methods is impressive. Thus, after endovascular occlusion of the testicular vein relapses constitute $26 \%$, after Ivanissevych operation - up to $23 \%$ $[2,3]$, after laparoscopic occlusion of the testicular veins - up to $8 \%$, after application of intervenous vascular anastomosis relapses occur in $2 \%$ of cases [4, 5]. These are the facts causing the topicality of morphological examinations of the venous structures of the spermatic cord.

Early diagnostics of varicocele by means of phleborenotesticulography, tensometry, duplex scanning determines the choice of an optimal method of surgery and further prognosis of this pathology. Interpreting of the results of examination and the volume of surgery on varicocele is connected with a detailed and comprehensive study of the anatomy of veins of the spermatic cord. At the same time, analysis of scientific sources is indicative of the fact that evidence of the anatomy of the pampiniform plexus and testicular veins is isolated, disembodied and not systematized. The data concerning topographic-anatomical peculiarities of the spermatic cord veins in the perinatal period of human ontogenesis are practically absent. Therefore, a topical task of normal anatomy concerning individual and age peculiarities of the structure of the pampiniform plexus and testicular veins in the perinatal period of human ontogenesis requires further solution.

Objective: to detect topographic-anatomical peculiarities of the pampiniform plexus and testicular veins in the early period of human ontogenesis.

Materials and methods. The study was conducted on 70 dead fetuses and 15 dead human male newborns. At first dead fetuses and newborns were measured, vascular injection was performed, and fixed in $10 \%$ neutral formalin solution during 3 weeks. Between the stages of the study specimens were kept in $5 \%$ formalin solution.

To detect topographic-anatomical peculiarities of the venous pampiniform plexus and testicular veins in early human ontogenesis the whole complex of morphological methods of examination used in the 
following succession for the rational conservation of the material: 1) anthropometry, 2) vascular injection, 3) radiography, 4) micro- and macroscopy, 5) preparing topographic-anatomical sections, 6) histological examination, 7) morphometry, 8) graphic reconstruction, 9) statistical processing of the digital data.

The angles and size of anatomical structures were measured by means of trammel, protractor, and eyepiece with micrometer. The longest longitudinal size was considered the length of the testicle, the longest transverse size was its width, and the biggest anterior-posterior size was its thickness.

Injection of the vessels was performed with the aim of their further dissection and macro-, microscopic examination and radiography. To study the connection of the venous testicular system and adjacent organs radiographic method of examination was used. After injection of vessels by means of radioopaque mixtures on the base of barium sulfate, lead or iron minium, the specimens were fixed during 10 days, after that review radiography on the apparatus EDR$750 B$ was conducted. In some cases radio-opaque mixtures were prepared on the base of a radio-opaque substances and dye with the aim of simultaneous study of the arteries and veins on one specimen.

Under control of a binocular magnifying glass on the fixed specimens testicles were dissected depending on their location, the testicular veins and adjacent structures were carefully separated.

To prepare topographic-anatomical sections horizontal sections of the trunk fixed in $10 \%$ neutral formalin solution were washed in water during 24 hours, after that they were saturated with $25 \%$ gelatin solution at the temperature of $37^{\circ} \mathrm{C}$. After cooling and hardening of gelatin the blocks were cut according to the size of the sections, then they were consolidated in $20 \%$ formalin solution during 6 hours. During all the stages of the study photos were made and recorded.

To study spatial micro-organization and dynamics of topographic-anatomical interrelations of the testicular vessels the method of graphic reconstruction was used, enabling not only to examine anatomical formations in the volumetric image but to detect its shape and size as well.

Results and discussion. The protein testicular membrane contains centrifugal veins collecting blood from the testicular septa and passing transversally to the longitudinal axis of the testicle into the partial septum of testis (mediastinum testis, Highmore's body) where they are connected with the centripetal veins and form the venous plexus around the branches of the testicular artery. In early fetal period centrifugal veins look like separate practically parallel to each other branches, but with time connections appear be- tween them and in 7-8-month fetuses they have a loop external structure. It is connected with the fact that separate venous branches are going to the mediastinum testis transversally to its longitudinal axis making anastomosis between them. Close to the mediastinum testicular veins are grouped in the networks around two branches of the testicular artery. Such venous plexus consists of the vessels of a clustering shape surrounding them like a network.

Histological sections of the fetuses reveal from 5 to 9 veins around every branch of the testicular artery, and on histological sections and macro-specimens of the testicles of newborns the number of veins around every artery decreases to $4-5$. On the specimens of testicles of 4-7-month fetuses some veins have a dead end, forming dilations which are indicative of the continuing processes of vascular formation. In 8month fetuses the venous plexus is spindle-shaped. In the caudal supratesticular region the veins of the spermatic duct form anastomosis with the venous plexus around the testicular arteries. They are of a prolonged-oval shape and surround this duct and artery of the spermatic duct by 3-4 trunks forming an original network as well. The venous plexus of the spermatic duct forms anastomosis with veins accompanying the arteries of the levator muscle and habenula of the testicle and collecting blood from the membranes of the testicle and the spermatic cord. At the beginning of the fetal period the venous wall is not formed yet: it consists only of the endothelium and thin subendothelial layer, the elements of blood are found in the lumen of these vessels. At the end of the fetal period the venous wall is practically formed, it consists of the endothelium, subendothelial layer, surrounded by the connective tissue, and a thin muscular membrane is seen.

Structural rebuilding of the venous system of the testicle (reduced number of veins and their shape in the content of plexus, formation of the pampiniform venous plexus) and the process of testicular descending cause irregular dynamic changes of the size of the venous plexus. Thus, accelerated growth rates of diameters of certain veins in the plexus around branches of the testicular artery and spermatic duct take place at the beginning of the $5^{\text {th }}$ month and at the end of the fetal period. Retarding growth rates are found at the beginning of the fetal period and in 7-month fetuses. During 7-8 months the size of the veins in these plexuses decreases, which can be explained by intensive processes of their formation and structural rebuilding, formation of the pampiniform plexus and venous valves. At the beginning of the fetal period in the points of attachment of certain veins between themselves the endothelium duplicates are found directed 
along the blood flow which is the sign of valve formation. On histological sections of 7-month fetuses the valves of the testicular veins are found, and on 10month fetuses and newborns the valves of the pampiniform plexus and testicular veins are vividly seen. They are mostly found in the right and look like cusps-duplicates of the endothelium. On the transverse and oblique-transverse sections of the abdominal portion of the testicular veins usually 2-3 cusps of the valves are found. On longitudinal sections the testicular veins are of a prolonged oval and spindle-like shape, on transverse sections - spherical, and in the places of valves - star-shaped. The valves of the testicular veins are found to be very labile, sometimes they may be absent which is an additional risk of occurring congenital varicocele. We have not found clear signs of valve formation in fetuses on the level of visceral venules. It may be suggested that the process of their formation continues after birth.

At the end of the $7^{\text {th }}$ month when testicles descend into the inguinal canal, the connections between the venous plexus around the testicular artery, the plexus of the spermatic duct and its artery on the level of the supratesticular head are found. This period may be considered an initial stage of formation of the pampiniform plexus. The process of testicle descending into the inguinal canal creates preconditions for the formation of anastomosis between the venous plexes of the testicle and supratesticle on the level of deep inguinal ring, and functioning of anastomosis with the veins of the peritoneum, anterior-lateral abdominal wall, venous plexuses of the pelvis and skin of the scrotum. Thereby, the veins of the peritoneum, deep muscularaponeurotic layer of the anterior-lateral abdominal wall, and levator muscle of the testicle in particular, tale part in the formation of the pampiniform plexus. At the end of the $7^{\text {th }}$ month of the intrauterine development the venous system of the testicle generally resembles the structure of the mature organism.

The asymmetry of the size of diameter and the shape of the lumen of veins in the plexus of the spermatic duct was found, in the right these parameters are more changeable than in the left. On the level of the head of the right supratesticle there are dilated round vascular lumens of the venous plexus, and the distance between the spermatic duct and its artery is much bigger than in the left. Behind the borders of the supratesticle the venous plexuses are going along the spermatic duct and its artery forming anastomosis between them, which is the base to suggest the existence of the common venous plexus around these structures. In 4-7-month fetuses the venous plexuses around branches of the testicular arteries are going upwards transversally crossing the ureters till the point of emptying into the hollow vein (vena cava) in the right and left renal vein in the left, forming anastomosis with the veins of adjacent organs and structures. Such anastomosis is formed by the peritoneal veins and with the vascular system of the spermatic duct, ureter, anteriorlateral abdominal wall, renal capsule, vertebral column in particular. Anastomoses with superficial femoral veins, ascending transverse vein, veins of the scrotum, and venous plexus of the pelvis are found. Due to this fact venous blood of the testicle has accessory ways for the outflow in the system of the inferior hollow vein, opposite veins, and through the peritoneal veins in the mesenteric area of the descending and sigmoid colon into the system of the hepatic portal vein.

Conclusions. 1. In early period of human ontogenesis the testicle and its venous system in the shape of plexus is located in the retroperitoneal space; magistralization of the testicular veins begins on the $6^{\text {th }}$ month of the intrauterine development and lasts to the period of birth. 2. The formation of the pampiniform plexus of the testicle begins since the $7^{\text {th }}$ month of the intrauterine development, which is caused by the process of testicle descending into the inguinal canal. 3 . Testicles of the fetuses and newborns possess accessory ways of venous outflow: into the veins of the anterior-lateral abdominal wall, superficial veins of the lower limb, peritoneal veins, ureters, renal capsule, and vertebral column.

Prospects of further study. The study of embryotopographic processes of morphogenesis of the vascular testicular bed is considered to be reasonable which enables to clarify the peculiarities of its anlage better.

\section{References:}

1. Грубник В.В.Новые подходы к классификации варикочеле / В.В. Грубник, В.А. Боровикова // Хірург.України. - 2007. - № 2. - С. 93-96. 2. Выюбор способа хирургического лечения варикочеле / С.Н. Шамраев, А.Я. Канана, И.А. Бабюк, Д.Н. Шамраева // Вестн. неотложной и восстановительной мед. - 2013. - T. 14, № 1. - C. 21-23. 3. Borruto F.A. Laparoscopicvsopen varicocelectomy in children and adolescents: review of there cent literature and meta-analysis / F.A. Borruto, P. Impellizzeri, P. Antonuccio [et al.] // J. Pediatr. Surg. - 2010. - Vol. 45, № 12. - P. 2464-2469. 4. Нариси перинатальної анатомії/ [Ю.Т.Ахтемійчук, О.М.Слободян, Т.В.Хмара та ін.]; за ред. Ю.Т.Ахтемійчука. - Чернівці: БДМУ, 2011. - 300 c. 5. Тандилава Р.3. Оптимизация хирургической коррекции варикоцеле у детей / Р.3. Тандилава, 3.P. Тандилава // Клін. хірург. - 2012. - № 6. - С. 40-43. 


\section{ПЕРИНАТАЛЬНАЯ АНАТОМИЯ ЛОЗОВИД- НОГО СПЛЕТЕНИЯ И ВЕН ЯИЧКА}

Резюме. Интерпретация результатов исследования и объем оперативных вмешательств по поводу варикоцеле связано с детальным и обстоятельным изучением анатомии вен семенного канатика. Вместе с тем анализ научных источников показывает, что сведения об анатомии лозовидного сплетения и яичковых отрывочные, единичные и несистематизированы. Исследование проведено на 70 трупах плодов и 15 трупах новорожденных человека мужского пола. Установлена асимметрия величины диаметра и формы просвета вен сплетения семявыносящего протока, справа эти параметры изменчивее, чем слева. На уровне головки правого надъяичка заметны расширенные округлые просветы сосудов венозных сплетений, а расстояние между семявыносящих протоков и ее артерией значительно больше, чем слева. За пределами надъяичка венозные сплетения направляются вдоль семявыносящего протока и его артерии, анастомозируя между собой, что является основанием утверждать о существовании общего венозного сплетения вокруг этих структур.

Ключевые слова: лозовидное сплетение, вены яичка, плод, анатомия, человек

\section{PERINATAL ANATOMY OF THE PAMPINI- FORM PLEXUS AND TESTICULAR VEINS}

Abstract. Interpreting of the results of examination and the volume of surgery on varicocele is connected with a detailed and comprehensive study of the anatomy of veins of the spermatic cord. At the same time, analysis of scientific sources is indicative of the fact that evidence of the anatomy of the pampiniform plexus and testicular veins is isolated, disembodied and not systematized. The study was conducted on 70 dead fetuses and 15 dead human male newborns. The asymmetry of the size of diameter and the shape of the lumen of veins in the plexus of the spermatic duct was found, in the right these parameters are more changeable than in the left. On the level of the head of the right supratesticle there are dilated round vascular lumens of the venous plexus, and the distance between the spermatic duct and its artery is much bigger than in the left. Behind the borders of the supratesticle the venous plexuses are going along the spermatic duct and its artery forming anastomosis between them, which is the base to suggest the existence of the common venous plexus around these structures.

Key words: pampiniform plexus, testicular veins, fetus, anatomy, human

Bukovinian State Medical University (Chernivtsi)

Надійшла 21.11.2014 p. Рецензент - проф. Булик Р.С. (Чернівці) 